\title{
1. History of the concept of sustainable development
}

The concept of sustainable development results from a combination of fragmented approaches towards the notion of development. Aware of poverty and inequality, the United Nations (UN) proclaimed four development decades between 1960 and 2000. Over time, the main constituents of development policy became formulated and debated. In the first decades, sectorial approaches abounded whereby economic perspectives of development were paramount; while such perspectives were linked to social issues very early, though in an unstructured way, the environmental perspective came into play quite separately.

Soon, it became apparent that the sectorial approaches were limited and lead to a lack of legitimacy. While developed countries' interests were mainly of an economic and ecological nature, developing countries emphasized the economic and social perspectives. Thereby, the economic claims of developing countries differed quite significantly from those countries which were economically better off. The consequence was a blockade which culminated in the formulation of the concept of sustainable development in the late 1980s. Since the concept of sustainable development focused specifically on the needs of future generations, it succeeded in providing an all embracing umbrella for the wide range of development agendas.

Since this period, international actors have been struggling for understanding and deepening of this promising conceptual approach. The concept of sustainable development has become anchored and widely diffused in the international debate, but it has remained rather intangible. In order to make it more operational, much work still needs to be done. This work, however, presumes an understanding of where the concept of sustainable development comes from and in which discourses it has been and is embedded. Hence, in this chapter, some related key debates of the last five decades, particularly of UN institutions, will be presented by throwing the spotlight on the guiding UN policy documents. 


\subsection{SECTORIAL APPROACHES TOWARDS DEVELOPMENT: FROM 1960 TO 1990}

The sectorial debates which took place between 1960 and 1990 dealt either with economic, social or environmental challenges. Consequently none of those were, per se, straightforward and concise. Rather, arguments were in many cases ambivalent and debated controversially. In the following sections, some of the most decisive economic, social and environmental debates of that time will be presented. ${ }^{1}$

\subsubsection{Economic Debate}

\subsubsection{1 (Preferential) trade not aid}

Impressed both by the process of decolonization and the tragedy of several famines in the 1950s, the UN declared the first UN Development Decade by enacting in 1961 Resolution 1710 of the UN General Assembly. ${ }^{2}$ This resolution was mainly characterized by two aspects: developing countries needed economic growth, and this growth should be self-sustained. ${ }^{3}$ After years of colonialism, the young countries attempted to move away from earlier economic and structural dependencies. ${ }^{4}$

1 This historical analysis of the concept of sustainable development, which is based on original legal texts, has also been inspired by similar undertakings, such as those included in Gehne, K., Nachhaltige Entwicklung als Rechtsprinzip (Tübingen: Mohr Siebeck, 2011) (cited: Gehne, Nachhaltige Entwicklung als Rechtsprinzip); Schrijver, N., The Evolution of Sustainable Development in International Law: Inception, Meaning and Status (Leiden/Boston: Martinus Nijhoff Publishers, 2008); Cordonier Segger, M. C. and A. Khalfan, Sustainable Development Law, Principles, Practices, \& Prospects (New York: Oxford University Press, 2004); Odendahl, G., Das Recht auf Entwicklung - The Right to Development, Entstehungsgeschichte, systematische Stellung und Inhalt eines individuellen sowie kollektiven Menschenrechts und Grundprinzips der Völkerrechtsordnung (Aachen: Shaker Verlag, 1997), pp. 173-8 (cited: Odendahl, das Recht auf Entwicklung).

2 UN GA Resolution 1710 (XVI) of 19 December 1961, UN Development Decade, A programme for international economic co-operation (I), A/RES/1710 (XVI). The UN GA Resolutions launching the UN Development Decades have been based on the 1945 UN Charter, Art. 1(3). For the history of the term, see also Kahl, W., 'Nachhaltigkeit als Verbundbegriff', in: W. Kahl (ed.), Nachhaltigkeit als Verbundbegriff (Tübingen: Mohr Siebeck, 2008), pp. 1-35.

3 UN GA Resolution 1710 (XVI), Art. 1.

4 The UN General Assembly adopted several resolutions on anticolonialization, such as the UN GA Res. 1514 (XV) of 14 December 1960, Declaration on the Granting of Independence to Colonial Countries and Peoples, 
As a result it was felt that economic growth should not only be attained through a rise in development assistance and in private investment capital, but also through a strengthened integration of developing countries in the international market through trade. 5 The slogan 'trade not aid' particularly emphasized this aspect. Foreign exchange earnings should then assist in achieving self-sustained economic growth, in advancing industrialization, diversification and the development of a highly productive agricultural sector. ${ }^{6}$ Through a 'trickle down effect', the profit would then pass to the poorer population. As a consequence of this rationale, many newly independent countries, particularly African countries, became GATT ${ }^{7}$ contracting parties in the 1960s, and the United Nations Conference on Trade and Development (UNCTAD) was established in 1964.

Further, in the move away from colonization and the fight for structural reforms, developing countries increasingly insisted on 'differential treatment'. Raul Prebish, first Secretary-General of UNCTAD, initiated the debate by presenting a report in 1964 which introduced the concept of preferential treatment. ${ }^{8}$ One of Prebisch's main arguments was that preferential tariff rates on developing countries' manufactured products would help 'free those countries from heavy dependence on trade in primary products $[\ldots]^{\prime} .{ }^{9}$ As a result, UNCTAD and the Organisation for

A/RES/1514 (XV), or the UN GA Res. 1803 (XVII) of December 14, 1962, Permanent Sovereignty over Natural Resources, A/RES/1803 (XVII); cf. also the later adopted 1974 Charter of Economic Rights and Duties of the States, which states the sovereign and alienable right of every person 'to choose its economic system as well as its political, social and cultural systems in accordance with the will of its people, without outside interference, coercion or threat in any form whatsoever.' (A/RES/3281 (XXIX), Art. 1).

5 See UN GA Res. 1710 (XVI), Art. 2(a) which recommended 'to pursue policies designed to enable the less developed countries and those dependent on the export of a small range of primary commodities to sell more of their products at stable and remunerative prices in expanding markets, and thus to finance increasingly their economic development from their earnings of foreign exchange and domestic savings'.

6 See ibid, Art. 4(a).

7 World Trade Organization (WTO) General Agreement on Tariffs and Trade of 1994 (cited: GATT).

8 Prebisch, R., Towards a New Trade Policy for Development, Report by the Secretary-General of the United Nations Conference on Trade and Development (New York: UNCTAD, 1964).

9 Cottier, T. and M. Oesch, International Trade Regulation, Law and Policy in the WTO, the European Union and Switzerland (Bern/London: Staempfli, Cameron May, 2005), p. 562. 
Economic Cooperation and Development (OECD) took up intensive research into this issue which culminated in the GATT approval of a waiver in 1971. This waiver permitted developed countries henceforward to accord more favourable treatment to products that were imported from developing countries.

\subsubsection{Dependency theory and new international economic order (NIEO)}

In 1970, the UN General Assembly (UN GA) initiated the second UN Development Decade by issuing UN GA Resolution 2626. ${ }^{10}$ Contrary to UN GA Resolution 1710, this new resolution was far more comprehensive and read like a manual of action for both developed and developing countries for the ten years to come.

Under this Resolution, economic growth and integration into the world market continued to be an important element. However, the international community became more focused on the economic interdependencies between states and the duties of wealthy countries vis-à-vis poorer countries. Due to the continuing poverty in large parts of the world and despite increasing growth rates, the classic approach towards development and economic reform was challenged and complemented by the dependency theory. This theory suggested that poor underdeveloped states were exploited by wealthy developed nations in order to sustain their own economic growth. ${ }^{11}$ The assumption that the economies of all states were interdependent resulted in a duty placed upon all members to work towards greater equity and justice.

Based upon such views, in 1974 the UN General Assembly adopted a set of further documents which were to initiate a 'New International Economic Order' (NIEO). The objective of the NIEO was to tackle effectively the structural root causes of the development divide. The 1974 Declaration on the Establishment of a NIEO introduced guiding principles for a NIEO, and the 1974 Charter of Economic Rights and Duties of States codified concrete economic rights and duties. ${ }^{12}$

10 UN International Development Strategy for the Second United Nations Development Decade of 24 October 1970, A/RES/2626 (XXV).

11 See, eg. Ferraro, V., 'Dependency Theory: An Introduction', in G. Secondi (ed.), The Development Economics Reader (London: Routledge, 2008), pp. 58-64.

12 See UN GA Res. 3201 (S-VI) of 1 May 1974, Declaration on the Establishment of a New International Economic Order, A/RES/3201 (S-VI); UN GA Res. 3202 of 1 May 1974, Programme of Action of a New International 
The NIEO project became heavily politicized, given that it occurred during the time of the Cold War. The conflict ignited over provisions such as Art. 4(d) of the Declaration on the Establishment of a NIEO that claimed 'the right of every country to adopt the economic and social system that it deems the most appropriate for its own development', or Art. 4(p) that claimed access of developing countries to the achievements of modern science and technology without any promise of protection for direct investment originating from developed countries. Western countries neither accepted authoritative allocation mechanisms, such as the adjustment of export prices, ${ }^{13}$ nor concrete duties to financially cooperate 'free of any political or military conditions'. ${ }^{14}$ As a result, the NIEO project failed and the regulatory framework never became of a binding legal nature. However, its spirit continues to be present in more recent international trade and investment debates which take place along the North-South divide and regularly touch upon the idea of global justice.

Hence, despite the failure of the NIEO project, the Resolution which initiated the third Development Decade ${ }^{15}$ still mirrored the NIEO debate. This resolution was mainly driven by the conviction that economic and social development had its limits if the structural imbalances in the international economic system were not successfully tackled. Consequently, it pointed at the 'limitations of a strategy, when conceived within the framework of the existing system of international economic relations ...' ${ }^{16}$ As a result, the governments again reaffirmed solemnly their determination to establish a new international economic order, ${ }^{17}$ and the plea for non-reciprocal policies to the benefit of developing countries was reiterated: 'To this end, there should be more effective implementation ... of the principle of differential and more favourable treatment, on a non-reciprocal basis, of developing countries in order to enhance their market access and to increase their share of world trade ...' ${ }^{18}$

Economic Order, A/RES/3202 (S-VI); and UN Charter of Economic Rights and Duties of States of December 12, 1974, A/RES/29/3281 (XXIX).

13 See UN GA Res. 3201, Art. 4(j).

14 See UN GA Res. 3201, Art. 4(k).

15 UN GA Res. 35/56 of 5 December 1980 - International Development

Strategy for the Third United Nations Development Decade, A/RES/35/36.

16 Ibid., annex, I (2). (Preamble).

17 Ibid. I (2).

18 Ibid, III (52). 


\subsubsection{Brandt Report and interlocked welfare of nations}

A new aspect was brought into the economic development debate by the Brandt report 'North-South: A programme for survival' which was published in $1980 .{ }^{19}$ This report was expected to unblock the debate by dealing with the North-South divide from an ethical perspective.

The central merit of the report was to base its analysis upon the insight of a fully interdependent, common global economy, which comes with an 'interlocked welfare of nations'. ${ }^{20}$ The report argued that, from this perspective, it was not only in the interest of developing countries to solve the North-South divide, but of 'mutual interest' to both developed and developing countries: "North and South have more interest in common on a medium- and long-term basis than many have so far been able to recognize'. ${ }^{21}$ In order to bridge the divide, the report postulated 'creative partnerships'. ${ }^{22}$

In addition, the structural deficits of the global framework were again particularly emphasized. ${ }^{23}$ Interestingly, the economic growth paradigm was put into question by requesting that the "persistent confusion of growth with development' should be avoided. ${ }^{24}$ Rather, international economic policy should be purpose driven and should always bear in mind the human being as the relevant benchmark. ${ }^{25}$

For concrete measures, a five-year emergency programme was recommended. ${ }^{26}$ The recommendations were not implemented but the Brandt report received much publicity and significantly influenced the debate on global justice. The suggested link between economic development and social concerns was followed up by the 1986 Declaration on the Right to Development ${ }^{27}$ (see section 1.2.3.).

\subsubsection{Washington Consensus}

These concepts of mutual economic interdependency were contrasted in the 1980s by the 'Washington Consensus' which described a compilation

19 Brandt, W. et al., North-South: A Programme for Survival, Report of the Independent Commission on International Development Issues (London/Sydney: Pan Books, 1980).

20 Ibid, p. 18.

21 Ibid, p. 20.

22 Ibid, p. 23.

23 Ibid, p. 18.

24 Ibid, p. 23.

25 Ibid, p. 11.

26 Ibid, p. 276-7.

27 UN Declaration on the Right to Development of 14 December 1986, $\mathrm{A} / \mathrm{RES} / 41 / 128$. 
of macroeconomic policies which, during that decade, became accepted by neo-classical economists and Washington-based financial institutions as being inalienable premises of a successful economic development. The Washington Consensus contrasted the approaches which had been discussed in the context of the NIEO insofar as it aimed primarily at disciplining national economic policies, and not at building a new international economic framework.

The term 'Washington Consensus' was coined in 1989 by the economist John Williamson who merged the set of recommended macroeconomic policies to a standard reform package which was primarily targeted at crisis-ridden countries of Latin America. It included ten specific policy reform prescriptions, including fiscal policy discipline and tax reform; redirection of public spending from indiscriminate subsidies towards targeted provisions of key pro-growth and pro-poor services; interest rates that are market determined and moderate; competitive exchange rates; trade liberalization; 28 protection and liberalization of foreign direct investment; privatization of state enterprises; and the abolition of regulations that impede market entry or restrict competition, except for those justified on safety, environmental and consumer protection grounds. ${ }^{29}$ With time, these principles became elements of the structural adjustment programmes (SAPs) of the international financial institutions and shaped the conditionalities that applicants had to comply with. ${ }^{30}$

After a while, the term 'Washington Consensus' took on a slightly different meaning and became associated with neoliberal policies in general. It became an element de rigeur of the debates on the role of the state or on the impacts of liberal markets. Critics argued that the principles which governed the Washington Consensus were too rigorous and unduly restricted the policy space of countries. It was questioned whether they indeed contributed to an increase in growth rates ${ }^{31}$ and a criticism was that even in cases where the respective policies had improved economic stability and growth rates, the negative impacts were not adequately taken into account, while key issues such as equity,

28 With a particular emphasis on the elimination of quantitative restrictions.

29 Williamson, J., 'What Washington Means by Policy Reform', in J. Williamson (ed.), Latin American Readjustment: How Much has Happened (Washington: Institute for International Economics, 1990), ch. 2.

30 See eg. Lapeyre, F., Globalization and Structural Adjustment as a Development Tool (Geneva: ILO, 2004).

31 See eg. Amsden, A., The Rise of 'The Rest': Challenges to the West From Late-Industrializing Economies (Oxford: Oxford University Press, 2001). 
re-distribution and poverty alleviation were left unresolved or even changed for the worse. ${ }^{32}$ Similar to the Brandt report, this criticism challenged the interrelationship of economic and social perspectives. ${ }^{33}$

\subsubsection{Social Debate}

\subsubsection{Mistrust in the trickle down effect}

That development comes with a social perspective has always been clear, but the understanding of how economic and social perspectives relate to each other has varied over time. While in the first development decade, states had confidence in the 'trickle down effect' of economic growth, UN GA Resolution 2626 which initiated the Second Development Decade expressed a new mistrust in such an effect. ${ }^{34}$ The resolution rather demanded that economic policies be complemented by welltargeted social policies. ${ }^{35}$ These should bring about a more equitable distribution of income and wealth, substantially raise the level of employment, and improve facilities for education, health and nutrition, housing and social welfare. Consequently wealthier countries would have to assist developing countries in implementing social policies.

In general, Resolution 2626 made an attempt to re-focus the development discourse by stressing that the ultimate purpose of development was to 'provide increasing opportunities to all people for a better life' ${ }^{36}$. Such early demand for a focus on the 'basic needs of individual persons', and for illuminating the situation beyond the aggregate data of national

32 Among other prominent critics are Joseph Stiglitz (see Stiglitz, J., Globalization and its Discontents (New York: Norton, 2002) and Dani Rodrik (see Rodrik, D., Goodbye Washington Consensus, Hello Washington Confusion? (Harvard University, 2006)).

33 For a history of international economic law, see also Tietje, C., 'Begriff, Geschichte und Grundlagen des Internationalen Wirtschaftssystems und Wirtschaftsrechts', in C. Tietje (ed.), Internationales Wirtschaftsrecht (Berlin: De Gruyter, 2009), pp. 17-27 (cited: Tietje, Begriff, Geschichte und Grundlagen).

34 UN GA Resolution 2626.

35 Ibid, Art. 18. See also the 1974 Cocoyoc Declaration, adopted by the participants in the UNEP/UNCTAD symposium on 'Patterns of Resource Use, Environment and Development Strategies', Cocoyoc, Mexico, 8-12 October 1974. It states in ch 1 (about 'the purpose of development'): 'Our first concern is to redefine the whole purpose of development. This should not be to develop things but to develop man.'

36 Ibid, Art. 18. 
economies, linked the development agenda to the human rights framework which, at that time, was already generally recognized. The conceptual underpinning of such an interlinkage, however, was still missing.

\subsubsection{Right to development}

A concept to address the bridging of the development and the human rights agenda was introduced by the UN Declaration on the Right to Development ${ }^{37}$ which was adopted in 1986 by the UN General Assembly. As a reaction to the failure of the NIEO project, the international community had decided to approach the development agenda from a different perspective and, accordingly, the UN Declaration on the Right to Development stipulated a right to development both for individual persons and for 'all peoples' (see Art. 1). With this, right bearers were all individuals and all peoples, irrespective of their provenance, whether they were rich or poor, women or men, or suffered from human rights violations or not. ${ }^{38}$

The individual right to development as enshrined in the declaration vested each individual with the right to participate in and enjoy a development process which entails social, economic and environmental aspects. The dynamic character of the term 'development' implied a permanent shift towards the better. In contrast, the collective right to development stated the right of peoples to self-determination. Peoples shall decide by themselves what is best for them, with limits set by the human rights framework. ${ }^{39}$ Importantly, the right to development should not compete against human rights as enshrined in the International Covenants on Human Rights; rather, they should complement each other.

The UN Declaration on the Right to Development also included a set of duties. According to its Art. 3(1), states bear the primary responsibility, but international cooperation is also required: 'States have the duty to co-operate with each other in ensuring development and eliminating obstacles to development'. ${ }^{40}$ Article 3(3) of the declaration particularly

37 UN Declaration on the Right to Development of 14 December 1986, A/RES/41/128.

38 Being of a partly collective nature, the right to development became assigned to the 'third generation of human rights', a legal category which still comes with blurred contours. See eg. Kälin, W. and J. Künzli, Universeller Menschenrechtsschutz (Basel/Genf/München: Helbing\&Lichtenhahn, Nomos, 2005), p. 117-18 (cited: Kälin, Künzli, Universeller Menschenrechtsschutz).

39 See Art. 1(2) 1986 UN Declaration on the Right to Development.

40 Odendahl, for instance, argues in favour of a general duty of States to co-operate; see Odendahl, das Recht auf Entwicklung. 
built a bridge to the NIEO debate and the Brandt report by stating that states 'should realize their rights and fulfil their duties in such a manner as to promote a new international economic order based on sovereign equality, interdependence, mutual interest and co-operation among all States [...]'.

The UN Declaration on the Right to Development is of a non-binding nature, hence the legal nature of the right to development continues to be contentious. As a common expression of the signing states concerning what should be 'right,' 41 it is of strong moral content. ${ }^{42}$ The right to development has entered more recent declarations, such as the 1992 Rio Declaration on Environment and Development, ${ }^{43}$ or the 1993 Vienna Declaration on Human Rights (Vienna Declaration). ${ }^{44}$ Most prominently, the right to development became codified as a binding standard in the African Charter on Human and Peoples' Rights. ${ }^{45}$

With the formulation of the right to development, a shift in the concept of development had occurred. By choosing a rights-based approach, development policy, including structural adjustment, should henceforth not be an act of charity, but rather a compliance with legal duties. ${ }^{46}$

41 Kälin et al, Universeller Menschenrechtsschutz, pp. 84-5.

42 Aguirre, for instance, attributes to the right to development, if not binding force, but strong legal authority, which is about becoming binding law. He points at the near consensus adoption of the 1986 UN Declaration on the Right to Development, but also due to the existence of important follow-up institutions, see Aguirre, D., The Human Right to Development in a Globalized World (Hampshire: Ashgate, 2008), p. 108. Some scholars even argue that the right to development has become a general principle of law recognized by civilized nations in the sense of Art. 38 of the International Court of Justice, Statute, Annex to the Charter of the United Nations, 26 June 1945 (cited: ICJ Statute). For a comprehensive analysis of the right to development, see Odendahl, das Recht auf Entwicklung.

43 UN Rio Declaration on Environment and Development, Annex I to the Report of the United Nations Conference on Environment and Development of 12 August 1992 (A/CONF.151/26, Vol. I).

44 UN Vienna Declaration and Programme of Action of July 12, 1993, A/CONF.157/23.

45 African (Banjul) Charter on Human and Peoples' Rights of 27 June 1981, OAU Doc. CAB/LEG/67/3 rev. 5, 21 I.L.M. 58 (1982).

46 Lindroos argues that 'the right to development articulates the entitlement of the developing world.' See Lindroos, A., The Right to Development, Erik Castrén Institute Research Reports 2/1999 (Helsinki: Forum Iuris, 1999), p. 29. 
Failure to regulate the right to development in a binding convention shows how politically sensitive the issue is. ${ }^{47}$

\subsubsection{Environmental Debate}

\subsubsection{New concerns arise}

In addition to these developments, the 1970s gave rise to a new concern: the environment and its limits. This new focus was not least due to an increase in environmental disasters ${ }^{48}$ and the more sophisticated mass media which brought these incidents closer to the people. Already UN GA Resolution 2626,49 which had initiated the Second Development Decade, included a brief chapter on environmental protection. It was one of the few times that the UN General Assembly directed its call equally upon all governments - irrespective of their development status - and asked them to respect the limits of the natural environment. Hence, through this resolution, governments promised that they would "promote activities that will help to maintain the ecological balance on which human survival depends' ${ }^{50}$

At the same time, the report of the global think tank, Club of Rome, entitled 'Limits of Growth' was released.51 Published in 1972, it has sold 30 million copies in more than 30 translations. The book predicted that economic growth could not continue indefinitely because of the limited availability of natural resources, particularly of oil. The 1973 oil crisis further increased public attention on this issue.

47 For the idea of a Convention on the Right to Development, see Bunn, I., The Right to Development and International Economic Law, Legal and Moral Dimensions (Oxford/Portland: Hart Publishing, 2012).

48 In this period such disasters occurred as the chemical accidents in Yusho (Japan) or in Bitterfeld (GDR: German Democratic Republic), both in 1968, or in Seveso (Italy) in 1976. Some accidents had happened in nuclear plants, such as in Idaho Falls (USA) in 1961, in Monroe (USA) in 1966, in Lucens (Switzerland) in 1969, in Sellafield (GB) in 1973, Greifswand (GDR) in 1975 or Three Mile Island (USA) in 1979. Marine pollution had occurred in large oil spills such as the one in the Scilly Isles (UK) in 1967, the Gulf of Oman in 1972, in Urquiola (Spain) in 1976 or in the Gulf of Mexico and Trinidad/Tobago, both in 1979.

49 UN International Development Strategy for the Second United Nations Development Decade of 24 October 1970, A/RES/2626 (XXV).

50 Art. 72 UN GA Resolution 2626.

51 Meadows, D. H, J. Randers, D. L. Meadows, and W. W. Behrens, The Limits to Growth: A Report for the Club of Rome's Project on the Predicament of Mankind (New York: Universe Books, 1972). 


\subsubsection{Evolving of international environmental law and the mistrust of developing countries}

In the wake of such occurrences, international environmental law began to evolve. While some environmental treaties had already been concluded in earlier years, namely in the field of maritime protection, the bulk of multilateral environmental agreements came into force from the 1970s onwards.

An important driver was the UN Conference on the Human Environment in Stockholm (UNCHE), which took place in 1972,52 and which is regularly cited as having given birth to international environmental law. It constituted the first UN conference dealing with environmental degradation from a general, conceptual perspective as well as establishing a link between development and the environment. Developing countries expressed concern that the focus on the limits of economic growth might hamper their economic development perspectives. Hence, the final 1972 UN Declaration of the United Nations Conference on the Human Environment (Stockholm Declaration) ${ }^{53}$ mirrored not only the new fears of environmental damage, but also the preoccupation that environmental protection could occur at the expense of poorer countries' development goals. ${ }^{54}$

\subsubsection{Evolving of environmental concepts and principles aside from development discourse}

Further into the 1970s, the concept of the 'common heritage of mankind', including the 'natural' and the 'cultural' heritage of mankind, evolved. The natural heritage of mankind envisaged the protection of natural resources of global interest, such as deep sea, outer space, the moon, the Antarctic or the air in general. ${ }^{55}$ In parallel, the cultural heritage of mankind ensured universal protection of exceptional cultural heritage of mankind. Both concepts found legal codification in the Convention

\footnotetext{
52 In the same year, the United Nations Environment Programme (UNEP) was founded.

53 UN Declaration of the United Nations Conference on the Human Environment of 5-16 June 1972, 11 I.L.M. 1416.

54 This is particularly reflected in principles 8, 9 and 11 of the 1972 Stockholm Declaration.

55 e.g. Agreement Governing the Activities of States on the Moon and Other Celestial Bodies, 5 December 1979, 1363 U.N.T.S. 3.
} 
Concerning the Protection of the World Cultural and Natural Heritage, which restricted policy space of countries to a necessary extent. ${ }^{56}$

Further, some overarching environmental principles were introduced by the World Charter for Nature which was adopted by the General Assembly in 1982.57 While referring to several earlier resolutions, it reiterated the importance of sound ecosystems for human development. Its first general principle pointed at the limits set by nature and stated laconically 'nature shall be respected and its essential processes shall not be impaired'. By advocating both the productive use and protection of the ecosystem through adequate management, the Charter introduced the term 'sustainable' by stating: 'Ecosystems and organisms, as well as the land, marine and atmospheric resources that are utilized by man, shall be managed to achieve and maintain optimum sustainable productivity [...]. 58

During the Third Development Decade, international regulatory work on environmental protection continued. Some multilateral agreements were concluded; among the most prominent were the 1985 Vienna Convention for the Protection of the Ozone Layer ${ }^{59}$ and the 1989 Basel Convention on the Control of Transboundary Movements of Hazardous Wastes and their Disposal. ${ }^{60}$ Despite some initial allusions to the link between the environment and development, however, until 1989, the environmental pillar remained to one side and was mainly uncoupled from social and economic development discourse.

\subsection{RECONCILIATION BY THE CONCEPT OF SUSTAINABLE DEVELOPMENT}

\subsubsection{Brundtland Report: An Eye on Interconnectedness}

Whilst the international community uncovered new and common concerns, it became more and more apparent that the various regulatory provisions were fragmented, and that such fragmentation threatened to

\footnotetext{
56 Convention Concerning the Protection of the World Cultural and Natural Heritage of 16 November 1972.

57 UN World Charter for Nature of October 28, 1982, A/RES/37/7.

58 Art. 4 World Charter for Nature, Part I (General Principles).

59 Vienna Convention for the Protection of the Ozone Layer, Vienna, 22 March 1985.

60 Basel Convention on the Control of Transboundary Movements of Hazardous Wastes and their Disposal of 22 March 1989 (cited: Basel Convention).
} 
impair the legitimacy and effectiveness of the legal systems. In particular, developing countries were reluctant to adhere to environmental goals as long as their economic and social concerns were not taken seriously. Hence, in 1983, the UN General Assembly commissioned a report that would deal with environmental issues in an integral way. ${ }^{61}$ The report was to examine ways of overcoming the singular approach and to construct a consistent environmental framework, by taking into account the needs of developing countries. Its terms of references introduced the terms 'sustainable development', 'mutual supportiveness' and 'interrelationship between environment and development'. As a result, the World Commission on Environment and Development (WCED) ('Brundtland Commission'62) prepared and issued its report 'Our Common Future' in 1987.63

An important merit of the Brundtland Report was to explain and highlight that global challenges were interlinked and inter-dependent. It showed in an illustrative way, by including many examples, that policies could only be successful if they dealt with an issue comprehensively. ${ }^{64}$ The report entered into 'areas of population, food security, the loss of species and genetic resources, energy, industry, and human settlements realizing that all of these are connected and cannot be treated in isolation one from another.' ${ }^{65}$ It stated that ecology and economy should become interwoven at all levels of governance 'into a seamless net of causes and effects' ${ }^{66}$ This insight became prominently expressed in the slogan 'from one Earth to one World' ${ }^{67}$.

61 See the UN GA Resolution 38/161 of 19 December 1983, Process of Preparation of the Environmental Perspective to the Year 2000 and beyond, A/Res/38/161. Other early reflections about the relationship of environment and development were undertaken by the International Union for the Conservation of Nature who published the 'World Conservation Strategy' in 1980. It introduced the term 'sustainable development', which was, however, of limited scope.

62 Named by its Norwegian chair Gro Harlem Brundtland.

63 World Commission on Environment and Development, Our Common Future (Oxford: Oxford University Press, 1987) (cited: Brundtland Report).

64 The report dealt with 'areas of population, food security, the loss of species and genetic resources, energy, industry, and human settlements realizing that all of these are connected and cannot be treated in isolation one from another.'. Ibid, p. 11.

$\begin{array}{ll}65 & \text { Ibid, p. } 11 . \\ 66 & \text { Ibid, p. } 5 . \\ 67 & \text { Ibid, ch. } 1 .\end{array}$ 
In particular, the report contrasted the 'concept of essential needs' with the 'concept of environmental limits'. ${ }^{68}$ It concluded that environmental limits would only be respected if essential needs were met, and that vice versa - the meeting of essential needs implied that the limits of environmental resources were respected: 'A world in which poverty is endemic will always be prone to ecological and other catastrophes.' 69

A further merit was the introduction of the long-term perspective as an overarching principle. Accordingly, policies would only be sustainable if they were not only beneficial to present, but also to future generations. By making this intergenerational aspect prominent, the report came up with the concept of sustainable development. Its prominent definition reads:

Sustainable development is development that meets the needs of the present without compromising the ability of future generations to meet their own needs. It contains within it two key concepts: (a) the concept of 'needs', in particular the essential needs of the world's poor, to which overriding priority should be given; and (b) the idea of limitations imposed by the state of technology and social organization on the environment's ability to meet present and future needs. ${ }^{70}$

With this concept of sustainable development, the report assumed that the different economic, social and environmental objectives could be reconciled. Thus, despite the existence of life-threatening challenges, the report relied on the concept of hope. ${ }^{71}$ It promoted faith in innovation and in the resilience of human society. As for the economic sector, a new era of economic growth was called for. 'Zero growth' theories were rejected, ${ }^{72}$ but it was considered relevant that benefits from growth should be fairly shared and that the financially more powerful states and individuals should bear more responsibility: 'Sustainable global development

68 Ibid, p. 8.

69 Ibid, p. 8.

70 Ibid, p. 43. Often in debate, it is only referred to the first sentence, what falls short given the nature of the multi-faceted concept.

71 Ibid, p. 1.

72 See ibid, p. 1: 'Our report, Our Common Future, is not a prediction of ever increasing environmental decay, poverty, and hardship in an ever more polluted world among ever decreasing resources. We see instead the possibility for a new era of economic growth, one that must be based on policies that sustain and expand the environmental resource base. And we believe such growth to be absolutely essential to relieve the great poverty that is deepening in much of the developing world.' 
requires that those who are more affluent adopt life-styles within the planet's ecological means.' 73

Finally, according to the Brundtland Report, sustainable development was not static but a dynamic, democratic process. ${ }^{74}$ Nevertheless, this process needed to be oriented and managed towards predetermined goals. Such a process would not be straightforward, and it required political will. ${ }^{75}$ The report criticized the fact that existing institutional gaps exacerbated fragmentation rather than promoted coherence. ${ }^{76}$

The General Assembly, when adopting the Brundtland Report in $1987,{ }^{77}$ elevated the concept of sustainable development to the new core 'guiding principle' of international action. ${ }^{78}$ As a consequence, it called upon all governments and the United Nations system to review their policies, based upon a sustainable development perspective. ${ }^{79}$

\subsubsection{Rio 1992: Earth Summit}

The UN Conference on Environment and Development (UNCED; also Earth Summit), held in Rio de Janeiro in 1992, was explicitly convened in order to provide the concept of sustainable development with more precise contours. Several documents emanated from the broadly-attended meeting, ${ }^{80}$ among them the Rio Declaration and Agenda $21 .{ }^{81}$ Both

73 Ibid, p. 16.

74 Ibid, p. 8.

75 See ibid, p. 9.

76 Ibid, pp. 9-11.

77 UN GA Resolution 42/187 of 11 December 1987, Report of the World Commission on Environment and Development, A/RES/42/187.

78 See ibid, Preamble.

79 Ibid, Arts. 7-9.

80 The Rio Conference will later be called the 'Earth Summit', not at least due to the huge number of participants which set new standards for further conferences. The strong involvement of NGOs, in particular, constituted a new phenomenon, such as the parallel NGO forum which has been attended by around 17,000 people. See http://www.un.org/geninfo/bp/enviro.html (last accessed 16 April 2015).

81 UN Conference on Environment and Development, Agenda 21, June 1992, A/CONF.151/26/Rev.1 (Vol. I) and UN Agenda 21 of 14 August 1992 (A/CONF.151/26, Vol. II). The other two major documents which were adopted in Rio 1992 were the Convention on Biological Diversity of 5 June 1992 (cited: CBD) and the UN Framework Convention on Climate Change of 1992, CCC/ INFORMAL/84, GE.05-62220 (E) 200705 (cited: UNFCCC), both now basic environmental documents. 
documents contributed significantly to further conceptualization of sustainable development. In particular, the Rio Declaration did so by framing principles that provided the concept of sustainable development with guidance and Agenda 21 by delineating an all-embracing programme of action.

\subsubsection{Rio Declaration: Legal Conceptualization of Sustainable Development}

The 27 principles of the Rio Declaration on Environment and Development provided an important cornerstone for sustainable development. They are still providing guidance to sustainable development discourse, where their exact reading is a prerequisite to sustainable development theory. Principle 3, the core principle of the Rio Declaration, explicitly refers to the wording of the Brundtland Report: 'The right to development must be fulfilled so as to equitably meet developmental and environmental needs of present and future generations.' While referring to the term 'equitably', both the developmental ${ }^{82}$ and the environmental needs were attributed with equal weight. Further, principle 3 implicitly included both the principles of intra-generational and inter-generational equity.

The other principles of the Rio Declaration equally delineated the framework of sustainable development. Principle 1 stated that sustainable development needed to be measured against the welfare of human beings: 'Human beings are at the centre of concerns for sustainable development ...' Principle 2 confirmed the sovereignty of each state over its natural resources; however, it explicitly stated that such a right comes with the responsibility not to cause damage. Principle 4 called for coherent development policies and the 'mainstreaming' of environmental policies, and principle 5 reiterated the importance of poverty eradication. Principle 7 explicitly highlighted the principle of common but differentiated responsibilities in environmental protection, by acknowledging that developed countries were more accountable for already existing damage. Principle 9 pointed at the importance of technical and scientific innovation, and the particular role that youth and indigenous people play in this respect. Principles 10 and 20 emphasized the importance of full participation, in particular, the full participation of women. Principle 12 reiterated the necessity of a supportive international economic system.

82 'Developmental needs' includes both the social and economic aspects of developments. 
Principles 15 and 16 endorsed the precautionary principle, and the polluter pays principle. Principle 17 pointed at the importance of informed decision making, requiring (environmental) impact assessments for proposed activities that are likely to have a significant adverse impact. Principle 25 brought peace and security in relation to development and environmental protection, and principle 26 highlighted the necessity of peaceful dispute settlement procedures (in environmental disputes). Principle 27, finally, explicitly called for further development of international law in the field of sustainable development.

Hence, the Rio Declaration gave shape to the concept of sustainable development by delineating the framework within which policy action should be placed. Although it has remained of a non-binding nature, over the years, some of the legal principles have become part of the corpus of international customary law. This development was undoubtedly accelerated by the Rio Declaration.

\subsubsection{Agenda 21: Detailed Action Plan}

Agenda 21, a unanimously adopted 470-page action plan, constituted the action plan of the Rio Declaration. It listed numerous policies, plans, programs and processes for the actual implementation of sustainable development in the 21 st century, ${ }^{83}$ and hence was aimed at giving guidance to all sorts of sustainable development policies, whether on a global, regional, national or local level. Agenda 21 identified a need for concrete action in areas such as production and consumption patterns, demographic dynamics, health conditions, agricultural and rural development, conservation of biological diversity or integrated decision making. It evoked the role of women, youth, NGOs and economic actors as actors of change, and so on. Since its adoption, Agenda 21 has been a relevant handbook for the development of further sustainable development initiatives at various levels of governance, despite some obvious weaknesses, such as the omission of energy sector related issues.

In 1997, the UN General Assembly held a special session to appraise five years of progress on the implementation of Agenda 21 (Rio+5). The Assembly recognized progress as uneven. The validity of Agenda 21 was confirmed, and further actions were promised by the adoption of the Programme for the Further Implementation of Agenda 21.84 Particularly,

83 See http://www.un.org/esa/sustdev/documents/agenda21/english/agenda21 toc.htm (last accessed 16 April 2015)

84 UN GA Resolution S/19-2 of 28 June 1997, Programme for the Further Implementation of Agenda 21, A/RES/S-19/2. 
the importance of national sustainable development strategies by the year 2002 was emphasized. ${ }^{85}$ (For the follow-up conferences +10 and +20 , see section 1.4).

\subsubsection{The Development Perspective of Sustainable Development?}

Although both the Rio Declaration and the Agenda 21 assigned equal weight to all thematic dimensions, particular emphasis was laid on environmental protection. ${ }^{86}$ As a result, critics, mainly from developing countries, argued that the documents were biased and did not reflect the economic and social concerns of developing countries adequately. ${ }^{87}$

Such tension between stakeholders representing the environmental, development or economic community is characteristic of the sustainable development debate. It would inform the follow-up debate on sustainable development. In particular, while developing countries would fear a new form of eco-colonialism hostile to development concerns, developed countries would be afraid that developing countries would continue to neglect their environmental obligations (see section 1.4.5.).

\subsubsection{Innovation and Sustainable Development}

Other critical voices argued that both the Rio Declaration and Agenda 21 underestimated the key role of innovation for sustainable development. According to these critics, the documents attributed too much weight to precaution, and applied a top-down instead of a bottom-up approach, relying upon the regulating power of governments instead of upon entrepreneurs' initiatives. ${ }^{88}$

This criticism is invalid because both the Rio Declaration and Agenda 21 suggested that 'development' implied a dynamic process of change,

85 Ibid, Art. 24(a).

86 See Principle 7, Principle 17 and Principle 26 of the 1992 Rio Declaration.

87 See eg. Fuentes, X., 'International Law-making in the Field of Sustainable Development: The Unequal Competition between Development and the Environment', in N. Schrijver and F. Weiss, International Law and Sustainable Development (Leiden: Martinus Nijhoff Publishers, 2004), pp.7-37 (cited: Fuentes, Unequal Competition).

88 See eg. Aerni, P., 'Mobilizing Science and Technology for Development: Peter Rieder's Commitment to the Promotion of Sustainable Development in the Developing World', in Möhring, A. et al (Zürich: Schweizerische Gesellschaft für Agrarwirtschaft und Agrarsoziologie, 2005). 
and also emphasized the important role of innovation. ${ }^{89}$ Broad participation was advocated as an important condition of change, while providing for the inclusion of bottom-up initiatives. ${ }^{90}$ Thereby, the documents invoked the precautionary principle to ensure an adequate balancing of opportunities and risks.

Hence, it can be argued that the Rio Documents were fairly balanced, but that their reception in policy and civil society differed widely. As a consequence, the search for more concrete contours is still ongoing.

\subsection{THE SEARCH FOR A PATHWAY OF INTERACTION}

Following the Brundtland Report and the Rio documents, the concept of sustainable development became the core development paradigm of the United Nations. This was reflected in nearly every policy document which was issued by the international community in the 1990s, where clear reference was made to the concept of sustainable development, at least in their preamble. ${ }^{91}$

Also in the 1990s, first attempts were made to delineate the concept with clearer contours, but many issues still remained unresolved. In fact, this Fourth Development Decade (effectively the first 'sustainable development decade') was marked by a tug of war between the various pillars of the concept of sustainable development, each pillar trying not to lose influence in the debate. Questions such as the following were raised and disputed: How much weight should be given to the different pillars of the concept of sustainable development? Should the social, the environmental or the economic aspects become most relevant? If weighted equally, what would this imply? Were the different goals indeed mutually supportive, or were they rather exclusive? And would the fulfilling of social and environmental objectives not, first of all, require considerable economic growth? Or, rather, does economic growth not per se imply the violation of environmental limits and lead to more inequality?

As a result, while the individual branches of international public law as such became strengthened in the 1990s, the integration of the different branches of international law still remained fragmentary, despite the many references to 'sustainable development' and its promises.

\footnotetext{
89 See Principle 9 of the Rio Declaration and chapter 21 of Agenda 21.

90 See Principles 20-22 of the 1992 Rio Declaration.

91 See for example the preamble to the WTO Marrakesh Agreement Establishing the World Trade Organization of 1994.
} 


\subsubsection{Conferential Activism}

Ambitious World Conferences, characterized by a huge attendance and side events by NGOs, significantly contributed to the strengthening of international legal principles and to the search for interlinkages on the basis of the concept of sustainable development. The most relevant conferences in this respect follow.

\subsubsection{1993 World Conference on Human Rights}

At the World Conference on Human Rights of 1993, in Vienna, representatives of 171 states adopted, by consensus, the Vienna Declaration and the Programme of Action on Human Rights. ${ }^{92}$ Both documents reflected the conviction that the global human rights framework needed to be strengthened.

The conference realized several major conceptual achievements. First, the universality and indivisibility of all human rights were explicitly recognized. ${ }^{93}$ While the Vienna Declaration confirmed the human rights principles which had evolved during the past 45 years, it stated in Art. 5: "All human rights are universal, indivisible and interdependent and interrelated.' ${ }^{94}$ This principle of universality and indivisibility aimed at overcoming the divide between social, economic and cultural human rights on the one side and political and civil human rights on the other side, which had characterized the time of the Cold War. Subsequently, a significant number of countries - which had been so far only members of the International Covenant on Civil and Political Rights (ICCPR) ${ }^{95}-$ decided to ratify the International Covenant on Economic, Social and

92 UN Vienna Declaration and Programme of Action of 12 July 1993, A/CONF.157/23 (cited: Vienna Declaration)

93 See also Kälin, Künzli, Universeller Menschenrechtsschutz, pp. 22-24.

94 The interesting wording of Art. 51993 Vienna Declaration reads: 'All human rights are universal, indivisible and interdependent and interrelated. The international community must treat human rights globally in a fair and equal manner, on the same footing, and with the same emphasis. While the significance of national and regional particularities and various historical, cultural and religious backgrounds must be borne in mind, it is the duty of States, regardless of their political, economic and cultural systems, to promote and protect all human rights and fundamental freedoms.'

95 International Covenant on Civil and Political Rights of 16 December 1966, A/RES/2200A (XXI) (cited: ICCPR). 
Cultural Rights (ICESCR), ${ }^{96}$ which gave social, economic and cultural rights more weight and brought them to the fore.

Further, the link between (sustainable) development and human rights was conceptualized: 'Democracy, development and respect for human rights and fundamental freedoms are interdependent and mutually reinforcing. ${ }^{97}$ Hence, development would definitely no longer be an act of grace. Rather, the fulfilment of the indivisible basic civil, political, social, economic and cultural rights was henceforth perceived as a necessary precondition to development and a must. With this commitment, the international community explicitly passed from 'basic needs' to the 'rights based' approach.

In addition, the conference strengthened the framework of women's rights by supporting the appointment of a Special Rapporteur on Violence against Women; also, the post of a High Commissioner for Human Rights was established, and the Vienna representatives called for the universal ratification of the Convention on the Rights of the Child.

\subsubsection{1995 World Summit for Social Development}

Further, the World Summit for Social Development ('Social Summit'), held in Copenhagen in 1995, was convened to tackle the social problems facing the planet, particularly the vast extent of poverty: 'We are witnessing in countries throughout the world the expansion of prosperity for some, unfortunately accompanied by an expansion of unspeakable poverty for others ...' 98 This gathering, one of the largest ever, contributed significantly to the advancement of international social law beyond the human rights framework. It was concluded with the adoption of the Copenhagen Declaration on Social Development ${ }^{99}$ including ten commitments, and the Programme of Action of the World Summit for Social Development. ${ }^{100}$

96 International Covenant on Economic, Social and Cultural Rights of 16 December 1966, A/RES/2200 A (XXI) (cited: ICESCR).

97 Art. 8 ICESCR.

98 Part A, 13 of the 1995 Copenhagen Declaration on Social Development, see next footnote.

99 UN Copenhagen Declaration on Social Development, Annex I to the Report of the World Summit for Social Development of March 6-12, 1995, Copenhagen, A/CONF/.166/9.

100 UN Programme of Action on the World Summit for Social Development, Annex II to the Report of the World Summit for Social Development of March 6-12, 1995, Copenhagen, A/CONF/.166/9. 
The Copenhagen Declaration on Social Development applied the concept of sustainable development as a guiding concept: 'We are deeply convinced that economic development, social development and environmental protection are interdependent and mutually reinforcing components of sustainable development, which is the framework for our efforts to achieve a higher quality of life for all people.' ${ }^{101}$ However, in order to emphasize the importance of the social aspects of development, the term 'social and people-centred sustainable development' 102 was introduced.

Hence, the documents reflected sustainable development thinking from the perspective of social policies. Plenty of statements took up the 'sustainable development' language on interdependency and developed it further. The inter-connectedness of social and economic policies built a central argument. The first principle stated that economies should be directed to meeting human needs more effectively. ${ }^{103}$ It was pointed out that the 'achievement of sustained social development required sound, broadly based economic policies', ${ }^{104}$ promoting 'the equitable distribution of income and greater access to resources through equity and equality of opportunity for all'. ${ }^{105}$ As to the link to the environmental objectives, it was explicitly emphasized that the protection of environmental resources was dependent upon equitable social development: 'Equitable social development that recognizes empowering the poor to utilize environmental resources sustainably is a necessary foundation for sustainable development.' 106

\subsubsection{1995 World Conference on Women}

The World Conference on Women, Beijing 1995, dealt with gender equality, a particular aspect of social justice. ${ }^{107}$ Again a broadly attended meeting, ${ }^{108}$ it resulted in the Beijing Declaration and the Platform for

\footnotetext{
101 Art. 6 Copenhagen Declaration on Social Development.

102 Introduction to the Copenhagen Declaration on Social Development.

103 Part B, Art. 26(a) Copenhagen Declaration on Social Development.

104 Art. 26(e) Copenhagen Declaration on Social Development.

105 Art 26(g) Copenhagen Declaration on Social Development.

106 Art. 6 Copenhagen Declaration on Social Development.

107 See Art. 14 Beijing Declaration and Platform for Action, in Report of the Fourth World Conference on Women of 17 October 1995, A/CONF.177/20 (cited: Beijing Declaration).

108 Almost 50,000 women and men gathered, among them representatives of 189 governments and thousands of NGOs (http://www.un.org/geninfo/bp/women. html (last accessed 16 April 2015).
} 
Action. ${ }^{109}$ The documents were considered follow-up documents to the 1979 Convention on the Elimination of All Forms of Discrimination against Women (CEDAW), ${ }^{110}$ to which governments renewed their commitment. ${ }^{111}$

Both the Declaration and the Platform for Action were built on the sustainable development concept. ${ }^{112}$ They centred on the argument that equality between women and men and poverty were two faces of the same coin. Without poverty eradication, progress in the improvement of gender relations would be almost unthinkable. Poverty caused inequalities between women and men to persist: '[...] this situation is exacerbated by the increasing poverty that is affecting the lives of the majority of the world's people, in particular women and children ...' ${ }^{113}$

Vice versa, poverty eradication presumed gender equality:

Eradication of poverty ... requires the involvement of women in economic and social development, equal opportunities and the full and equal participation of women and men as agents and beneficiaries of people-centred sustainable development. ${ }^{114}$

Women in rural areas, for example, were considered important agents of development who needed equal access to productive resources, education and public services. ${ }^{115}$

Such linking of gender equality to the process towards sustainable development became broadly recognized after the conference. A proliferation of gender mainstreaming tools followed, and gender mainstreaming policies were introduced in each development agency, be it at the national or international level. ${ }^{116}$

\footnotetext{
109 Beijing Declaration.

110 Convention on the Elimination of All Forms of Discrimination against Women of 18 December 1979, A/RES/34/80.

111 Art. 81995 Beijing Declaration.

112 See Art. 361995 Beijing Declaration.

113 Ibid, Art. 6.

114 Ibid, Art. 16.

115 Ibid, e.g. Art. 26.

116 See eg. World Bank, Integrating Gender into the World Bank's Work: A Strategy for Action (Washington: World Bank, 2002).
} 


\subsubsection{Direction Setting in International Economy and Finance}

\subsubsection{Revival of the growth paradigm}

In the field of economics, different approaches were promulgated in the 1990s. The UN GA Resolution which heralded the Fourth Development Decade ${ }^{117}$ re-emphasized the need for higher growth rates, ${ }^{118}$ despite the newly introduced concept of sustainable development to which it referred. ${ }^{119}$ This conclusion was due to disappointment regarding a failed Third Development Decade in which the growth promises had been wiped out by adverse developments. ${ }^{120}$ While some developing countries had succeeded in sustaining quite high growth rates, for most others, 'the decade was one of falling growth rates, declining living standards and deepening poverty'.121

This re-orientation towards the growth paradigm reflected, not least, the spirit of the time. The collapse of the Soviet Union allowed for an undisputed revival of liberal economic theories. However, contrary to the Washington Consensus, the resolution brought back into focus the responsibility of developed countries towards developing countries. It demanded, in particular, that the problems of external indebtedness be resolved $^{122}$ and that the trade regime become more supportive to developing countries' interests, ${ }^{123}$ in order to allow for the process of industrialization to accelerate. ${ }^{124}$ Not least, such claims led to the integration of agricultural trade into the renewed international trade framework.

\subsubsection{Uruguay Round and Foundation of the WTO}

Hence, in the 1990s, a major step was achieved in international trade regulation. In 1994, the Uruguay Round was concluded and resulted in the establishment of the World Trade Organization (WTO). ${ }^{125}$ From then on, the WTO built an institution that would host 15 multilateral trade

\footnotetext{
117 General Assembly A/res/45/199, 21 December 1990.

118 Ibid, para. 17.

119 Ibid, para. 14 lit. b.

120 Ibid, Preamble.

121 Ibid, para. 3.

122 Ibid, para. 36 holds: "the net transfer of resources to developing countries on the aggregate turned negative because of the burden of debt-service payments'.

123 Ibid, para. 46.

124 Ibid, para. 71.

125 See the WTO Marrakesh Agreement Establishing the World Trade Organization of 1994 (cited: WTO Agreement).
} 
agreements, some plurilateral trade agreements and a range of ministerial decisions and declarations.

Among the multilateral agreements assembled were those which primarily dealt with classical tariff barriers, such as the 1947 General Agreement on Tariffs and Trade (GATT 1947) ${ }^{126}$ or the 1994 General Agreement on Trade in Services (GATS), ${ }^{127}$ both based upon the idea of progressive liberalization. Also non-tariff barriers were addressed, for example, by the Agreement on the Application of Sanitary and Phytosanitary Measures (SPS Agreement). ${ }^{128}$ Structurally different from any other WTO Agreement was the Agreement on Trade-Related Aspects of Intellectual Property Rights (TRIPS Agreement) ${ }^{129}$ that amounted to the prime attempt to harmonize intellectual property regulation. ${ }^{130}$ Also for the first time, trade in agriculture became multilaterally disciplined by the Agreement on Agriculture (AoA). Finally, based on the principle of 'single undertaking', the multilateral agreements were legally combined. Henceforth, they could only be amended 'all in one' through a 'package deal'.

The debate on sustainable development did not leave the WTO untouched, although the institution formally was and is not part of the United Nations. The Preamble of the Marrakesh Agreement explicitly referred to the concept of sustainable development by stating primary goals, such as raising standards of living or ensuring full employment. ${ }^{131}$ These goals would, however, be aspired to within the limits set by sustainable development, while allowing:

for the optimal use of the world's resources in accordance with the objective of sustainable development, seeking both to protect and preserve the environment and to enhance the means for doing so in a manner consistent with their respective needs and concerns at different levels of economic development. ${ }^{132}$

Other entry points would ensure the balancing of economic, social and environmental interests within the trade regime, such as the reference to non-trade concerns in Art. 20 lit. c of the WTO Agreement on Agriculture

\footnotetext{
126 WTO General Agreement on Tariffs and Trade of 1947 (cited: GATT).

127 WTO General Agreement on Trade in Services of 1994 (cited: GATS).

128 WTO Agreement on the Application of Sanitary and Phytosanitary Measures of 1994 (cited: SPS Agreement).

129 WTO Agreement on Trade-Related Aspects of Intellectual Property

Rights of 1994 (cited: TRIPS Agreeement).

130 Cottier/Oesch (International Trade Regulation), p. 916.

131 Preamble to the 1994 WTO Agreement.

132 Ibid.
} 
of 1994 (AoA). ${ }^{133}$ Accordingly, in the continuation of the reform process, account should be taken of:

non-trade concerns, special and differential treatment to developing country members, and the objective to establish a fair and market-oriented agricultural trading system, and the other objectives and concerns mentioned in the preamble to this agreement. ${ }^{134}$

This topic will be further developed in Part III of this volume, particularly in section 6.5 .

\subsubsection{From structural adjustment programs to poverty reduction strategies}

In the Fourth Development Decade, the policies of the most relevant international financial institutions, the International Monetary Fund and the World Bank, also experienced a move towards more integrated approaches. ${ }^{135}$ As already discussed in section 1.1.1.4, the Structural Adjustment Programs (SAPs) which introduced conditionalities for lending, had been broadly criticized for implementing generic free market policy, without taking account of the specific needs of a country. ${ }^{136}$ As a reaction to this critique, and as a direct consequence of the debate on more coherent integrated approaches, the Poverty Reduction Strategy Papers (PRSPs) would henceforth replace the SAPs. The borrowing countries were asked to draw up country-owned PRSPs which would increase the borrowing country's involvement and take into account country specific sensitivities. ${ }^{137}$

133 In the following cited AoA.

134 Art. 20 AoA.

135 The annual World Bank's World Development Report of 1990 for the first time explicitly dealt with 'poverty', after having focused in earlier years on topics such as financial security, environmental economics, or terrorism. See World Bank, World Development Report 1990: Poverty (New York: Oxford University Press, 1990).

136 See e.g. Stiglitz, J. E., 'More Instruments and Broader Goals: Moving Toward the Post-Washington Consensus', in G. Kochendorfer-Lucius and B. Pleskovic (eds), Development Issues in the 21st Century (Berlin: German Foundation for International Development, 1999), pp. 11-39.

137 Whether the PRPSs lived up to their promises or not, is contentious. Critical voices argued that their content turned out to be quite similar to the SAP's content, with the financial institutions still being too involved in the policy making process. See eg CIDSE-Caritas Internationalis, PRSP, 'Are the World Bank and IMF delivering on Promises? A Background Paper' (Brussels: CIDSE, 2004). 


\subsubsection{Concept of good governance}

Further, during the Fourth Development Decade, the concept of good governance emanated from the discourse of the Bretton Woods institutions with developing countries. 'Good governance' meant the governance standards with which developing countries were to comply. The concept allowed the donor community to assess governance structures in the borrowing country. Good governance was both a condition for and an objective of assistance.

At first, the concept of good governance was linked mainly to economic development and financial accountability. With time, the concept received a broader meaning, and became generally associated with democratic institutions and respect for human rights, ${ }^{138}$ and it was frequently argued that the related governance principles also constituted basic guidelines for sustainable development. ${ }^{139}$

The term 'good governance' introduced a 'normative dimension to the definition of governance.' 140 'Governance' itself entailed all instruments through which different policy stakeholders may exercise policy power. In order to make it tangible, the World Bank developed six indicators which assisted in assessing governance structures, namely: Participation and Accountability; Political Stability and Absence of Violence; Government Effectiveness; Regulatory Quality; Rule of Law; and Control of Corruption. ${ }^{141}$ This set of indicators was further developed by many international organizations. Besides the above-mentioned standards, which were mainly of a procedural nature, indicators which targeted the substantive content of decisions were developed, such as, for example, the actual implementation of human rights standards.

In contrast, the debate on 'global governance' dealt with good governance on a global level. It concerned the most effective interplay between the different levels of governance in a more globalized world. Since the report of the UN-funded Commission on Global Governance 'Our Global

138 Brown Weiss, E. and A. Sornarajah, 'Good Governance', in Max Planck Encyclopedia of Public International Law (2009).

139 See e.g. Caluser, M. and M. Salagean (eds), Good Governance in Multiethnic Communities: Conditions, instruments, best practices, ways to achieve and measure good governance at the local level (Ethnocultural Diversity Resource Center, 2007), p. 5.

140 Brown Weiss and Sornarajah, 'Good Governance', para. 2.

141 The 'World Governance Indicators WGI' were developed in the World Bank's programme, 'A Decade of Developing the Quality of Governance'. For a retrospective, see World Bank, A Decade of Measuring the Quality of Governance (Washington: World Bank, 2007). 
Neighbourhood'142 appeared in 1995 and recommended far-reaching reforms such as a global taxation system, a standing UN army, an Economic Security Council, a UN authority over the global commons, an end to the veto power of permanent members of the Security Council, a new parliamentary body of civil society representatives (NGOs), a new Court of Criminal Justice, ${ }^{143}$ and expanded authority for the Secretary General, reforms of the UN system have been hotly debated.

\subsubsection{Deepening of International Law and Fragmented Integration}

With these developments ${ }^{144}$ in the 1990 s, international public law was significantly strengthened. In order to ensure a follow-up process, the conferences were generally followed by 'five and ten years after' $(+5$, +10 ) evaluation conferences with huge attendance by civil society organizations accompanied by increased public perception.

Since at these conferences first attempts were made to bring the individual branches of law closer to each other, they constituted initial moves towards more coherence in international law. However, while the awareness of legal fragmentation increased, efforts to shape new and more coherent rules were often limited to references to the concept of sustainable development and related principles and concepts. Not least due to a lack of instrumental tools, coherency in law making was not addressed systematically (see section 1.1.1.4).

In addition, by the end of the 1990s, it became apparent that the 'implementation' of the legal settings remained deficient. While the legal framework had developed widely, its effectiveness was in question. This lead to the proclamation of the end of the 'development decade' strategy; instead, henceforth, implementation would come to the fore.

\subsection{THE NEW MILLENNIUM: FOCUS ON IMPLEMENTATION}

At the beginning of the new Millennium, the international community decided against proclaiming a further development decade. Instead, the

142 Commission on Global Governance, Our Global Neighborhood (New York: OUP, 1995).

143 Which would be founded in 1998 in Rome.

144 Some further conferences could be mentioned, such as the World Summit for Children in New York, 1990 or Habitat II, second United Nations Conference on Human Settlements in Istanbul, 1996. 
focus would be on implementation. While many new international legal standards had been agreed upon in the past, significant changes towards the better were still missing. As a result, the following question posed by Nelson Mandela became a guideline for the decade to come: 'Will the legacy of our generation be more than a series of broken promises?' 145

\subsubsection{The Millennium Documents}

\subsubsection{Millennium Summit}

The foundation for a new orientation was laid at the 2000 Millennium Summit of the United Nations, held by the Millennium Assembly of the United Nations ${ }^{146}$. The Assembly adopted the Millennium Report and the Millennium Declaration. ${ }^{147}$ While the Millennium Report summarized past achievements and failures and explicitly appealed for urgent action, the Millennium Declaration came up with new tools with which to facilitate the measuring of progress. A series of concrete and time-bound development targets were introduced, such as the one on poverty eradication: 'We resolve further: To halve, by the year 2015, the proportion of the world's people whose income is less than one dollar a day and the proportion of people who suffer from hunger ...' ${ }^{148}$

In contrast to the three-dimensional approach of the concept of sustainable development, poverty was chosen and recognized as the most daunting problem the world would face in the new century. ${ }^{149}$

\subsubsection{The MDGs}

Based on the Millennium Declaration, a representative working group ${ }^{150}$ devised the Millennium Development Goals (MDGs) which were adopted by the UN in $2002 .{ }^{151}$ The eight goals were each complemented by specific targets and indicators in order to make the progress measurable. For example, Target 1 of MDG 1 set the target of 'halving, between

145 UNDP (2002) 'The Millennium Goals in Africa-Promises and Progress' Report prepared by UNDP and UNICEF for G8 Personal Representatives for Africa, June 2002, New York.

146 It was the 55th session of the General Assembly and convened in September 2000. (http://www.un.org/ga/55/ (last accessed 16 April 2015)).

147 UN Millennium Declaration of 18 September 2000, A/RES/55/2.

148 Ibid, Art. 19.

149 Ibid, Art. 38.

150 Composed of representatives from the UN, the World Bank, the OECD etc.

151 UN Secretary General, Report, Implementation of the United Nations Millennium Declaration (2002), GA A/57/270. 
1990 and 2015, the proportion of people whose income is less than one dollar a day'. ${ }^{152}$

As the Millennium Summit documents, the MDGs were particularly geared towards eradication of poverty, to which each MDG should contribute directly. Even MDG 7 on 'environmental sustainability' aimed directly at poverty eradication by 'halving, by 2015, the proportion of people without sustainable access to safe drinking water and basic sanitation'. As a result, the MDGs have been criticized for being too fragmented by emphasizing the poverty issue while losing sight of the pressing environmental problems. Indeed, the Secretary General admitted in his 2002 report that the MDGs reflected only one part of the driving factors of sustainable development. ${ }^{153}$ However, he justified the sectorial approach as it allowed for focus on implementation and measurement: 'Nevertheless, while the Goals may not by themselves constitute a comprehensive development vision, they are a measurable set of human development benchmarks ...' ${ }^{154}$ In fact, the MDGs have proven to be a forceful communication tool and an important guide for all kinds of development policy. Simple and concrete, the MDGs are accessible to the public and suitable for the media.

\subsubsection{A Global Partnership for Development}

\subsubsection{Monterrey Consensus}

In order to consolidate the promises of the Millennium Summit and of the MDGs, some 50 Heads of State, over 200 ministers, senior officials of the intergovernmental financial, trade, economic and monetary organizations and a whole range of leaders from the private sector and civil society convened in 2002 at the Monterrey Conference on Financing for Development. The overall aim of the gathering was to negotiate a global

152 MDG 1 set targets for the eradication of extreme poverty and hunger, MDG 2 for ensuring primary education, and MDG 3 for the promotion of gender equality. MDG 4 dealt with the reduction of child mortality, MDG 5 with the improvement of maternal health and MDG 6 with the combating of HIV/AIDS, malaria and other diseases. MDG 7 sought to ensure environmental sustainability and MDG 8 to develop a global partnership for development.

153 UN Secretary General, Report, Implementation of the United Nations Millennium Declaration, Follow-up to the outcome of the Millennium Summit, 2 September 2003, GA A/58/323, p. 9.

154 Ibid. 
'partnership agreement'. The conference was concluded with the Monterrey Consensus ${ }^{155}$ which dealt with four major issues, among them the mobilization of domestic and international resources; the need to increase the quantity and quality of aid; the need to identify ways of sustainable debt financing; and the need to improve coherence and consistency of the international monetary, financial and trading systems.

The Monterrey Consensus reiterated the developing countries' primary responsibility for their own development, mainly with respect to the mobilization of domestic and foreign direct investment. Good governance and a sound, development-friendly economic strategy were identified as paramount. It was agreed, however, that "even the best efforts of these countries to break out of the cycle of poverty, ignorance, disease, violence and environmental degradation are likely to be insufficient unless they can count on the support of the international community. ${ }^{156}$

As a consequence of the Monterrey Consensus, the Monterrey participants agreed on the prominent 0.7 per cent target: In the years to come, developed countries would invest 0.7 per cent of their gross national product (GNP) in official development assistance. ${ }^{157}$ This figure was decided against the background of declining shares in the previous years. ${ }^{158}$ If complied with, it would have led to an increase of at least US\$ 12 billion per year by 2006. This was considered an important step which would, however, still fall 'far short of the additional US\$ 50 billion needed to give developing countries a fair chance of meeting the Millennium development goals'. ${ }^{159}$

\subsubsection{Paris Declaration on Aid Effectiveness}

Another important implementation tool was the promotion of aid effectiveness. Hence, in order to improve coherence of aid flows, the Joint

155 UN, Financing for Development, Monterrey Consensus of the International Conference on Financing for Development (United Nations: 2003) (cited: Monterrey Consensus).

156 UN Secretary General, Letter to Heads of State and Government of the 'Group of Eight' (United Nations, 2002), p. 2.

157 Monterrey Consensus, para. 42.

158 'Since Rio, aid as a percentage of GNP has declined substantially, reaching its lowest level of 0.22 per cent in 1997. Having increased in the last two years of the 1990s, ODA as a percentage of GNP again fell back to 0.22 in 2000. Only five donor countries [...] have managed to meet the UN target of 0.7 per cent'. In Black, R. and H. White, Targeting Development, Critical Perspectives on the Millennium Development Goals (London: Routledge, 2004), p. 327.

159 UN Secretary General, Report, Implementation of the United Nations Millennium Declaration, GA A/57/270, para. 50. 
Progress toward Enhanced Aid Effectiveness was brought into being by the OECD. Its outcome, the 2005 Paris Declaration on Aid Effectiveness, ${ }^{160}$ was a reaction to the often arbitrary, hardly predictable and nationally divergent procedures of aid delivery and allocation. ${ }^{161}$ Hence, the Paris Declaration intended to contribute to the 'harmonization' and 'alignment' of aid delivery in order to attain 'aid effectiveness'. Terms such as 'ownership', 'managing for result' and 'mutual accountability' were further core elements. Thereby, the 2005 Paris Declaration targeted both 'donors' and 'partner countries'.162 Article 3 of the Declaration importantly called upon the involved parties to strengthen partner countries' national development strategies; 163 to increase alignment of aid with partner countries' priorities; to enhance donors' and partner countries' accountability, to eliminate duplication of efforts and to rationalize donor activities to make them as cost-effective as possible. The implementation process met with and continues to meet with much resistance as donors' aid policies have been historically associated with private economic and political interests. ${ }^{164}$ The 2008 Accra Agenda for Action was to further drive forward the process towards improved aid effectiveness. ${ }^{165}$

\subsubsection{Debt sustainability}

Debt sustainability added to the implementation catalogue. According to the Monterrey Consensus, sustainable debt financing was key to re-establishing financial viability of highly indebted developing countries. ${ }^{166}$ It called for vigorous and expeditious debt relief measures, and welcomed respective initiatives. ${ }^{167}$

160 Paris Declaration on Aid Effectiveness, Paris 2005.

161 See Sagasti, F., K. Bezanson, F. Prada et al., The Future of Development Financing: Challenges, Scenarios and Strategic Choices (Institute of Development Studies Sussex (IDS): 2005).

162 The use of a respectful wording - by naming the receiving countries 'partner countries' - puts the latter on the same level with the donor countries.

163 Including planning, budget and performance assessment.

164 See as an early voice e.g. Morgenthau, H., 'A Political Theory of Foreign Aid' (1962) 56(2) The American Political Science Review 300-9.

165 High Level Forum on Aid Effectiveness, 3rd, Accra Agenda for Action, 2008.

166 See for an overview of the debate e.g. UNCTAD, Compendium on Debt Sustainability and Development (New York, Geneva: UN, 2009).

167 Since debt relief would 'play a key role in liberating resources that can then be directed towards activities consistent with attaining sustainable growth and development'. See Monterrey Consensus, paras. 47 and 48. 
The most prominent initiative in this field, the Debt Relief under the Heavily Indebted Poor Countries (HIPC) Initiative, had already been launched in 1996 by the IMF and the World Bank. It aimed at ensuring that no poor country faced a debt burden which it could not manage. In 1999, a comprehensive review of the initiative strengthened the link between debt relief, poverty reduction, and social policies. Highly indebted countries with external debts above a certain margin could qualify for the program if they complied with certain criteria, such as pursuing a concrete poverty reduction strategy. In 2005, the HIPC Initiative was supplemented by the Multilateral Debt Relief Initiative (MDRI). The MDRI allowed for full debt relief of eligible debts by the IMF, the World Bank and the African Development Fund for countries completing the HIPC Initiative process, if meeting with certain additional criteria. Some 40 countries - generally LDCs - have so far benefited from the initiatives. ${ }^{168}$

The initiatives were endorsed due to strong pressure from civil society, though they were also criticized. Some argued that the initiatives rewarded those countries that had performed badly in the past. Others held that the initiatives should not only target LDCs, but all developing countries. ${ }^{169}$

\subsubsection{Doha Round: Trade regulation for development?}

The Monterrey Consensus further called on the international community to improve the coherence and consistency of the international monetary, financial and trading systems. ${ }^{170}$ In parallel, the Doha Trade Round was launched in 2001. The Doha Declaration's main objective was to further develop a growth-oriented world trading system: 'We are determined, particularly in the light of the global economic slowdown, to maintain the process of reform and liberalization of trade policy ...'. . $^{171}$

Beyond such a growth strategy, and due to political pressure exerted by developing member states, the Doha Declaration recognized that trade could and should serve as an engine for development out of poverty,

\footnotetext{
168 For an overview, see International Monetary Fund (IMF), Factsheet, 'Debt Relief under the Heavily Indebted Poor Countries (HIPC) Initiative', 2010. 169 See eg. Birdsall, N. and B. Deese, Beyond HIPC: Secure Sustainable Debt Relief for Poor Countries (Center for Global Development: 2004).

170 Monterrey Consensus, paras 52-67.

171 WTO Doha Ministerial Declaration of 20 November, 2001, WT/MIN(01)/ DEC/1 (cited: Doha Declaration), para. 1.
} 
which was why the WTO Agreements would be conducive to development. ${ }^{172}$ The Round became henceforth labelled as the 'Development Round' and raised high expectations; although, because of a standstill in negotiations, it was not concluded in the First Millennium Decade as had originally been intended (see section 6.5.3).

\subsubsection{World Summit on Sustainable Development and Follow-Up: Shift in Focus}

In 2002, when the aforementioned implementation tools came into being, the World Summit on Sustainable Development (WSSD) in Johannesburg was convened. As a follow-up to the Rio conference, its plan was to renew political commitment and support for sustainable development. This mandate was not easy to comply with as the conference came at a time of great disillusionment with the sustainable development process. As a result, implementation of legal promises would stand in the foreground. The conference concluded with the 2002 Johannesburg Declaration on Sustainable Development, ${ }^{173}$ the Johannesburg Plan of Implementation (JPOI) ${ }^{174}$ and a whole range of partnership initiatives for specific actions.

The WSSD documents built on the achievements made since Rio. However, although Art. 5 of the 2002 Johannesburg Declaration reiterated the equivalence of all three pillars of sustainable development, discourse in the JPOI mainly dealt with poverty eradication and development. Not least because of the 9/11 attacks, fear grew that social inequalities might be of a perilous nature. ${ }^{175}$ Thus, "poverty alleviation ... has become the fundamental objective that should galvanize the international community's efforts to promote the economic, social, and environmental dimensions of sustainable development'. ${ }^{176}$ In this sense,

172 See Doha Declaration, para. 2.

173 UN Johannesburg Declaration on Sustainable Development of 4 September 2002, A/CONF.199/L.6/Rev.2 (cited: 2002 Johannesburg Declaration).

174 UN Johannesburg Plan of Implementation of 4 September 2002, A/CONF.199/20.

175 See 2002 Johannesburg Declaration, para. 15: 'We risk the entrenchment of these global disparities and unless we act in a manner that fundamentally changes their lives the poor of the world may lose confidence in their representatives and the democratic systems to which we remain committed, seeing their representatives as nothing more than sounding brass or tinkling cymbals.'

176 Kimball, L., F. X. Perrez and J. Werksman, 'The Results of the World Summit on Sustainable Development: Targets, Institutions, and Trade Implications' (2002) 13 Yearbook of International Environmental Law 3-19. 
the focus of the Commission on Sustainable Development (CSD) debate had slightly shifted. ${ }^{177}$

\subsubsection{Environmental commitments: 'Precaution' and 'mutual supportiveness'}

Nevertheless, despite fewer references to the environment, the most concrete commitments in the WSSD documents were made with regard to environmental issues. ${ }^{178}$ Among the most prominent achievements was the general acceptance of the 'precautionary principle', an issue that had become increasingly politicized over the previous years (see section 3.3.3.1.). ${ }^{179}$ Further, the relationship between the trade and environment regimes was prominently addressed, ${ }^{180}$ and the principles of 'no hierarchy', 'mutual supportiveness' and 'deference' were implicitly established as constituting principles of coherence. ${ }^{181}$

\subsubsection{Public-private partnership}

The WSSD further promoted, as a new promising instrument of implementation, the Public Private Partnership (PPP) approach, ${ }^{182}$ which dealt with the mobilization of private capital for the promotion of development, and the aligning of private with public interests. Partnership initiatives for implementation by all relevant actors and in all combinations were to be encouraged. Based on this initiative, a broad debate on the optimal degree of integration of private actors in public processes and the privatization of public goods has followed. ${ }^{183}$

177 In the WSSD last plenary meeting, the "“fault line" between the rich and poor' was declared as the main threat to sustainable development. 17th plenary meeting and round up, ENV/DEV/J/35, 4 September 2002.

178 Kimball et al, 'The Results of the World Summit', p. 14.

179 Johannesburg Plan of Implementation, para. 109 (f). For a critical review, see e.g. Perrez, F. X., 'The World Summit on Sustainable Development: Environment, Precaution and Trade - A Potential for Success and/or Failure' (2003) 12(1) RECIEL 12-22.

180 Johannesburg Plan of Implementation, para. 98.

181 See Perrez, 'The World Summit on Sustainable Development', pp. 18-20.

182 See e.g. paras. 96 and 99 of the Johannesburg Plan of Implementation.

183 See e.g. Osborne, S. P. (ed.), Public-Private Partnerships, Theory and Practice in International Perspective (Routledge: London, New York, 2000), or Akintoye, A., M. Beck, and C. Hardcastle (eds), Public-Private Partnerships: Managing Risks and Opportunities (Oxford: Blackwell Science, 2008). 


\subsubsection{Microcredits: A panacea for development?}

Further instruments of implementation which attracted worldwide attention in the following years, and which would mainly evolve from public-private partnerships were the microcredit programs. The 2002 Johannesburg Declaration alluded to the relevance of this innovative financing mechanism which provided credit access to the poor. ${ }^{184}$ Subsequently, microcredit schemes came to be treated as a panacea for poverty alleviation. ${ }^{185}$

Microcredit schemes allow for provision of very small loans to poor entrepreneurs who are not considered 'bankable'. These low-threshold credit opportunities allow poor people to become entrepreneurs, and diversify the entrepreneur-structures of countries as a whole. ${ }^{186}$ In particular, poorer women became the focus of microcredit institutions and agencies worldwide. However, after some years of experience, microcredits also became more contoversial, since experience showed that, in order to be successful, a whole set of conditions needed to be met. ${ }^{187}$

\subsubsection{Impact assessment and evidence-based decision making}

The 2002 Johannesburg Declaration reiterated the need to undertake 'sustainable development mainstreaming' in decision making at all levels of policy. ${ }^{188}$ As a tool which could promote informed decision making, impact assessments were repeatedly advocated. Ex ante and ex post impact assessments of policy proposals were to provide evidence to inform the decision making process. While at the WSSD, environmental impact assessment procedures were at the core of the debate, over the years, both human rights impact assessments and sustainability impact assessments, mainly of trade proposals, would come to the fore. They were to become a cornerstone in sustainable development theory and debate (see section 2.8). ${ }^{189}$

1842002 Johannesburg Declaration, para. 9(a).

185 The debate was particularly promoted by the founder of the Grameen Bank, Muhammad Yunus, who won the Nobel Peace Prize in 2006.

186 For conceptual background, see e.g. Helms, B., Access For All: Building Inclusive Financial Systems (Washington: The World Bank, 2006).

187 See e.g. Sancar, A., 'Gender Responsive Development Cooperation' (2010) 58/10 Widerspruch 109-122.

1882002 Johannesburg Declaration, para. 19(a)-(d).

189 See e.g. Bürgi Bonanomi Elisabeth, 'EU Trade Agreements and Their Impacts on Human Rights and Sustainable Development', Study commissioned by the Deutsche Gesellschaft für Internationale Zusammenarbeit (GIZ) on behalf 


\subsubsection{Sustainable development and MDGs: two sides of the same coin?}

At the WSSD, the sustainable development community process again pushed for the recognition of sustainable development as the overarching goal to which all other goals were subordinated. As a result, it tried to treat the forceful MDG process as an integrative element of the sustainable development agenda, while the JPOI expressly endorsed the MDGs. ${ }^{190}$ In contrast, however, the catalogue of MDGs treated 'sustainability' as merely a goal among others, being particularly limited to the environment. ${ }^{191}$ In previous years, similar developments could be observed in international economic regimes which tended to comprehend sustainable development as an element among others, and not as an overarching goal (see section 6.5.1). ${ }^{192}$ Hence, the fight for the adequate positioning of the concept of sustainable development continued.

\subsubsection{Ongoing Standard Setting: Corporate Social Responsibility, Climate Change, Financial Regulation and so on}

The beginning of the new Millennium was characterized by a range of efforts to hold the private sector accountable for the social and environmental impacts of their activities. An attempt by the UN to install a treaty framework which would have codified direct rights and obligations of business enterprises failed. ${ }^{193}$ Hence, the 'corporate social responsibility' (CSR) of the first decade of the new Millennium consisted mainly of

of the German Federal Ministry for Economic Cooperation and Development (BMZ) (including position paper) (CDE/WTI/GIZ, 2014) (cited: Bürgi, EU Trade Agreements and HRIAs).

190 Kimball et al, 'The Results of the World Summit', p. 4.

191 Goal 7 is named 'ensure environmental sustainability' and deals with standards regarding forests, species and habitats, energy efficiency, greenhouse gases, ozone-depleting substances, safe drinking water, basic sanitation, and life condition of slum-dwellers.

192 See e.g. Art. 62001 Doha Declaration.

193 See UN Sub-Commission, Draft Norms on the Responsibilities of Transnational Corporations and Other Business Enterprises with Regard to Human Rights, E/CN.4/Sub.2/2003/12 (2003) (cited: UN Sub-Commission, Draft Norms). For illustrating the discussion of that time, see International Council on Human Rights, Beyond Voluntarism, Human rights and the developing international legal obligations of companies (Versoix: International Council on Human Rights Policy, 2002). 
newly created voluntary initiatives which sought to tame business activities and to embed them within social and environmental frameworks. ${ }^{194}$ With the 'due diligence' approach of John Ruggie, the UN Special Representative for Business and Human Rights from 2005 to 2011, the CSR agenda took a considerable step forward. Based on the 2011 Guiding Principles on Business and Human Rights, ${ }^{195}$ new (and ongoing) debates about how to strengthen respective regulatory frameworks $\operatorname{arose}^{196}$ (see section 7.1.1.13).

International norm setting continued in other domains, such as climate change (see section 7.1.2.6), and even benefited from new momentum in the food domain after the late-2000s food crisis and financial regulation after the late-2000s financial crisis (see section 7.3.1.5). Similarly to the Doha Agenda, conflicts in these regulatory fields, particularly in climate change, continued to centre around unresolved questions of global justice and the fair allocation of responsibilities in a global agenda. ${ }^{197}$ Until the present, the opportunity to deal with global justice and equity more systematically and thoroughly has not been taken.

At the same time, the structure of global governance has been in motion. With respect to international economic governance, new institutional arrangements, such as the G20, are associated with promise and challenge. Although the G20 - a group of 20 finance ministers and central bank governors - is often criticized for precluding many states, it is also intended to 'cross-cut regimes and create collaborative linkages between economic law and social issues such as food security and the environment' 198 and hence to bring about more coherence. In general, the question of what sort of governance architecture would be most conducive to a coherent outcome, will remain a core theme at both the global and local levels in the decades to come (see section 2.7).

194 See e.g. the UN Global Compact, 2000.

195 UN Guiding Principles on Business and Human Rights: Implementing the United Nations 'Protect, Respect and Remedy' Framework, 2011, A/HRC/17/31. 196 See e.g. the EU Strategy on Corporate Responsibility: EU Commission, Communication to the European Parliament, The Council, The European Economic and Social Committee and the Committee of the Regions: A renewed EU strategy 2011-14 on Corporate Social Responsibility, European Commission, Brussels, 25 October 2011, COM(2011) 681.

197 See as an illustrative example Khor, M., Risks and Uses of the Green Economy Concept in the Context of Sustainable Development, Poverty and Equity (Geneva: South Centre, 2011).

198 Kelly, C. and S. Cho, Promises and Perils of New Global Governance: A Case of the G20 (2012) 12 Chicago Journal of International Law 491-564. 


\subsubsection{Rio + 20: Emphasis on the Economic Pillar and Sustainable Development Governance}

The Earthsummit 2012 in Rio de Janeiro (also known as the Rio +20 Conference or UNCSD 2012) constituted a further, more recent attempt to make the aims of sustainable development more concrete. Under the weight of climate change and the late-2000s financial crisis, it had been decided to focus on the economic pillar of sustainable development. Following the work of the OECD on 'green growth' 199 and the United Nations Environment Programme (UNEP) on the 'green economy', 200 the primary themes of the Earth Summit 2012 were 'Green Economy in the Context of Sustainable Development and Poverty Eradication' and the 'Institutional Framework for Sustainable Development'.201

Concerning the former, the aim was to broadly debate ways in which the economy, including public procurement frameworks, could be fundamentally re-directed by using ecological incentives. ${ }^{202}$ The addendum, 'in the context of poverty eradication and sustainable development', made clear that continuity with the sustainable development agenda, including its social focus, was intended. Nevertheless, the theme 'green economy' was prone to criticism as many stakeholders feared that the social dimension would be dismissed or would play a minor role which would weaken the idea of sustainable development. Stakeholders questioned why the theme was not more aptly named 'sustainable economy' or 'green and social economy'. ${ }^{203}$ In view of such criticisms, the conference

\footnotetext{
199 See OECD, Towards Green Growth (Paris: OECD, 2011).

200 UNEP, Towards a Green Economy: Pathways to Sustainable Development and Poverty Eradication (UNEP, 2011).

201 See http://www.uncsd2012.org/about.html (last accessed 16 April 2015).

202 To the fore were incentives governed by fundamental principles of the environmental regime, such as the precautionary principle, the polluter pays principle or the principle of internalization of external costs. Incentives should be directed towards sustainable consumption and production patterns. In order to get there, a consistent distinction between renewable and non-renewable resources should be made, the whole product life cycle should be considered when assessing environmental impacts, welfare should be understood in a comprehensive way and the multi-functionality of ecosystem services considered. See e.g. Switzerland, Submission for UNCSD 2012 (Rio+20) of 28 October 2011, chapter 2 .

203 See e.g. the UNRISD conference on 'Green Economy and Sustainable Development: Bringing Back the Social Dimension' from 10-11 October, 2011. See also Khor, Risks and Uses of the Green Economy Concept in the Context of Sustainable Development, Poverty and Equity (Geneva: South Centre, 2011).
} 
organizers - and also submissions by states - had underlined the point that the concept of sustainable development should not be contested or even substituted by the green economy agenda, but rather deepened and strengthened. ${ }^{204}$ Hence, whereas a 'green growth' approach, as promoted by the OECD, had primarily centred on the combination of economic growth and resource efficiency in OECD countries, the green economy agenda promised to also include the social and global aspects of economy. ${ }^{205}$

Indeed, whereas the chosen term was unbalanced, the risk that the concept of sustainable development would become displaced was rather minimal given the many civil society reactions at the forefront of the conference, making clear that well-balanced approaches were needed. As an example, a comprehensive understanding of the green economy agenda was expressed in the proposal by Colombia to compile Sustainable Development Goals (SDGs) in the style of the MDGs, which was warmly welcomed by the public. Also, attempts to measure 'wellbeing' in a comprehensive way were high on the agenda (see section 2.5.5).

The second theme of the Earthsummit 2012 was named 'Institutional Framework for Sustainable Development'. The objective was to strengthen international sustainable development with the adoption of a new institutional architecture. While the work of the UN Commission on Sustainable Development (CSD) was generally criticized for its limitation and lack of authority, instead, clear targets, a concrete roadmap and strengthened review mechanisms should produce some relief. Some countries even suggested replacing the CSD with a new institution, such as a Sustainable Development Council or a larger sustainable development unit within the UN system. ${ }^{206}$ In addition, international environment governance was to be strengthened. This could occur by reforming the

204 See High-level Panel of the Secretary-General on Global Sustainability, 'Resilient People, Resilient Planet: A Future Worth Choosing', Report of 1 March 2012, A/66/700.

205 For an attempt to re-balance the concept of green economy and to identify related key guiding principles, see United Nations Division for Sustainable Development UNDESA, A Guidebook to the Green Economy, Issue 2: 'Exploring Green Economy Principles' (New York/Geneva: UN, 2012). See also UNCTAD, 'The Road to Rio+20, For a development-led green economy' (New York/Geneva: UNCTAD, 2011); and ILO (together with UNEP et al), 'Working towards Sustainable Development, Opportunities for decent work and social inclusion in a green economy' (Geneva: ILO, 2012).

206 See e.g. Switzerland, Submission for UNCSD 2012 (Rio +20), 26 October 2011. 
UNEP or by improving network structures which would unfold synergies among MEAs. ${ }^{207}$

The conference concluded with the Resolution 'The Future We Want' ${ }^{208}$ While expectations prior to the conference had been high, many participants were disappointed in light of the seemingly modest results. However, some promising processes have been initiated. ${ }^{209}$ Although a 'Green Economy Roadmap' did not find approval, governments agreed to install 'tool boxes' for good practices. ${ }^{210}$ As a result, the urgent need to adequately embed economy into the framework of sustainable development became more recognized.

Further, the principle of common but differentiated responsibility has been confirmed as a core element of the sustainable development agenda, although its contours still remain unclear. ${ }^{211}$ The UNEP will not undergo an in-depth reform, but universal membership in UNEP's Governing Council will be established, and ways to increase financial resources will be looked for. ${ }^{212}$ A Sustainable Development Council will not be established, but a 'High Level Political Forum on Sustainable Development' to which all 193 members of the UN shall belong. ${ }^{213}$ Importantly, it has been decided to work out a 'Sustainable Development Financing Strategy' by establishing an intergovernmental process which will allow thorough analysis of current financial mechanisms at the global level. ${ }^{214}$ The necessity to complement the GDP by a more comprehensive measurement of progress and wellbeing has been clearly affirmed. ${ }^{215}$ And most prominently, it has been decided to complement or even supersede the MDGs - after their expiry in 2015 - with Sustainable Development

207 See e.g. Wehrli, J., 'Clustering Assessment: Enhancing Synergies among Multilateral Environmental Agreements' (Center for Governance and Sustainability, Issue Brief 3, 2012).

208 UN Report of the United Nations Conference on Sustainable Development, including the 2012 Resolution 'The Future We Want' (New York: UN, 2012), A/CONF.216/16. (cited: UN Resolution 'The Future We Want').

209 For a short, comprehensive overview, see e.g. Weed, 'Das war Rio+20: Mau, mager, minimal; doch zum Katzenjammer besteht kein Grund. Informationsbrief Weltwirtschaft \& Entwicklung“ (W\&E 06-07/2012).

2102012 Resolution 'The Future We Want', para. 66.

211 Ibid, para. 15.

212 Ibid, para. 88.

213 Ibid, paras. 84-86.

214 Ibid, para. 255.

215 Ibid, para. 38. 
Goals (SDGs). ${ }^{216}$ This latter objective has risen to significantly inform most recent public debate ${ }^{217}$ (see section 1.4.6).

From a coherence perspective, however, it must be concluded that, while proposals to improve sustainable development governance were intensely debated, the issue of legal coherence had not been tackled systematically, neither prior to nor at the conference itself. Proposals relating to 'coherence and cooperation' did not reach beyond improved cooperation of agencies. This is the case even though related terms such as 'enabling environment', 'inclusive processes' or 'meaningful trade liberalization' were introduced or reaffirmed. ${ }^{218}$ Thus far, first proposals have been made towards specialized fora which would deal systematically with coherent law making by searching for improved coherence of treaties across pillars. ${ }^{219}$ Hence, in this area, much work still needs to be done (see section 4.1.2).

\subsubsection{Post-2015Agenda}

Currently, the Post-2015 Agenda is ongoing, which promises to provide the debate on sustainable development with new drive, not least by the drafting of SDGs. This latter process implies nuanced reconceptualizations of sustainable development. Besides the report of the High-level Panel on Global Sustainability ${ }^{22}$ and the UN Resolution 'The Future We Want', the report of the UN System Task Team entitled 'Realizing the Future We Want for All'221 is most influential. The latter refines the three-pillar approach by emphasizing the core values: 'human rights', 'equality' and 'sustainability'. It does not only refer to three, but to four key dimensions, by also including 'peace and security' (see Figure 2.2). Since 'one size does not fit all, the global partnership for development would need to be redefined 'towards a more balanced

216 Ibid, paras. 244-251.

217 See for an important follow up document: UN System Task Team on the Post-2015 UN Development Agenda, 'Realizing the Future We Want for All', Report to the Secretary-General (New York: UN, 2012).

218 See 2012 Resolution 'The Future We Want', e.g. para. 31.

219 See e.g. Mexico, Contribución ante la conferencia Rio+20, 1 November 2011.

220 High-level Panel of the Secretary-General on Global Sustainability, 'Resilient People, Resilient Planet: A Future Worth Choosing', Report of 1 March 2012, A/66/700.

221 UN System Task Team on the Post-2015 UN Development Agenda, 'Realizing the Future We Want for All', Report to the Secretary-General of June 2012 (New York: UN, 2012). 
approach among all development partners' in order to enable the transformative change to happen. ${ }^{222}$ The proposal of the open working group for sustainable development goals ${ }^{223}$ suggests a benchmark framework of 17 goals. If taken seriously, it has the potential to significantly advance policy coherence making at all levels of governance.

\subsection{IN CONCLUSION}

When working with the concept of sustainable development, it is helpful to keep its origins in mind. While the global community of the 1960s became strongly aware of the extensive poverty on this planet, the 1970s sharpened the eye for environmental risks and structural root causes for economic imbalances. The 1980s was marked by a shy rapprochement of the two 'préoccupations fondamentales', and by the late 1980s, the search for a synthesis of the different poles began and the concept of sustainable development was introduced. Finally, since the beginning of the new Millennium, implementation of legal promises has come to the fore. In this network of developments, a range of conceptual approaches towards sustainable development was developed and both global and domestic institutions were designed to assist in promoting and implementing sustainable development and to ensure coherent policy making (see Chapter 2). Notwithstanding all this, the search for more concrete contours of sustainable development goes on, while international actors look for a path which is situated in the sectorial but respects the whole. With this, the former chair of the German Council for Sustainable Development, Volker Hauff, was correct when he stated in a radio interview that 'we are still at the beginning of the sustainable development process which will keep the global society busy in the whole century to come'. ${ }^{224}$

\footnotetext{
222 Ibid, pp. i-ii, 1-43.

22319 July 2014.
}

224 Swiss Radio DRS 1, Tagesgespräch with Volker Hauff, former chair of German Council for Sustainable Development, 8 November 2007, broadcast 'Rendez-vous am Mittag', 13.00. 